\section{Pyrexia of Unknown Origin}

Dr. Percy B. Spurgin (London, W.1) writes in reply to "C. H. P." (September 9th, p. 516): This might be a case of "fatigue pyrexia," a not uncommon condition allied to "toxaemia of deficiency." I would suggest glucose twice a day, and haliverol, with special diet rich in vitamins. Undue exertion to be avoided, and rest insisted upon at the first sign of fatigue, for at least half an hour recumbent.

\section{Income Tax}

Colonial Service-Residence in United Kingdom

"H. P." is in the Colonial Medical Services, and is contemplating buying a residence here and returning to West Africa with his wife and child, leaving the residence in the occupation of relatives.

** If “H. P." retains a residence available for his use in this country, then he will be liable, as a British resident, for any financial year in which he spends time here. His liability would not extend to cover pay not remitted to or drawn in the United Kingdom.

\section{Increase in Partnership Share}

"L. M. BIRM." had a one-third share in a practice from January 1st, 1931, to January 1st, 1933, since when his share has been cne-half. On what basis should he be assessed for 1932-3 and 1933-4?

** The Income Tax Acts provide that an assessment in the case of a partnership shall be made on the firm as a separate entity, and that in computing the income of any member of the firm the ratio to be applied is his share of the firm's profits for the year of assessment-not necessarily the share applicable to the basis year. Consequently our correspondent's share of the firm's tax will be the amount applicable to $(1 / 3$ of $3 / 4+1 / 2$ of $1 / 4=) 3 / 8$ of the assessment for $1932-3$ and $1 / 2$ for 1 s33-4.

\section{Employment of Daughter.}

“J. H." employs his daughter " part-time as private secretary, and makes her an allowance valued at $£ 35$ per annum, $\notin 20$ of which is paid in cash, and the remainder represents board and lodging." The inspector of taxes will allow only the $£ 20$ cash payment.

** In the case of an employer the amount to be charged by him is the expense he incurs, whether it be paid to the employee in cash or expended in providing board and lodging. Where the employment is part-time, as in this case, and the total cost includes something other than an employer's burden, the only safe guide is what would be the cost on a quantum meruit basis. If the services of "J. H.'s" daughter as his private secretary are worth £35 a year to him, then he is entitied to deduct that sum, whether it is paid to her in cash or expended in providing board and lodging for her.

\section{LETTERS, NOTES, ETC.}

\section{Student Interchanges with Poland}

A correspondent who has recently visited a number of hospitals and clinics in Poland informs us that under the auspices of the Medical Association of the University of Warsav arrangements for holiday exchanges can be made between Polish medical students and those of other countries. The principle of the exchange is that a foreign student is received in the Polish hospitals and clinics, board and lodging being provided, on the condition that similar facilities be given to a Polish student abroad. The organization, which is anxious to get in touch with this country, has already made contact with seven foreign countries and has this year received sixty-nine foreign students. The interesting and historic city of Warsaw, with its many fine examples both of ancient and modern buildings, has a population of about $\mathbf{1 , 2 0 0 , 0 0 0}$. There are four State hospitals, with 276 beds fourteen public hospitals, with 4,894 beds; twelve hospitals belonging to philanthropic societies, with 1,048 beds; and twenty-six private hospitals, with 510 beds: in all, fifty-six hospitals and 6,728 beds. In addition to the hospitals there are many other matters of medical interest-notably, the State School of Hygiene and the Municipal Institute of Hygiene. Our correspondent is satisfied that experience of such differences in the details of hospital work and organization as will always be found in a foreign country cannot but tend to increased observation and reflection and to a broadening of outlook. His experience also suggests that the reception given to students from this country would be most hospitable and cordial. While many Polish doctors speak English, a working knowledge of. French would be a considerable advantage. All arrangements should be made through the Polish Embassy, but the Medical Association at Warsaw is prepared to give further information to prospective visiting students. The address of the asscciation is: Kolo Medyków, Uniwersytetu Warszawskiego, Warszawa, Chalubinskiego 5, Pulland.

\section{Testing of $\mathrm{pH}$}

We have received from the British Drug Houses Ltd., Graham Street, London, N.1, a copy of the third edition of their useful and interesting sixteen-page booklet, $p H$ Values: What They Are, and How to Determine Them, by T. Tusting Cocking, F.I.C., together with a new catalogue of indicators, accessories, and compact outfits, used in making tests of hydrogen-ion concentration. The wares offered are of particular interest to physiologists, biochemists, and those concerned with public health, but the "B.D.H. capillator" is especially commonded to general practitioners.

\section{Exhibits of Medical Science}

Among the most interesting exhibits in the Hall of Science at the Chicago World Fair are those contributed by the Research Laboratories and Museums embraced by the Wellcome Research Institution, London. Models are shown of the institution itself, of the floating laboratory presented by Sir Henry Wellcome to the Sudan Government for use on the Nile, and of the mobile field laboratory given to the British War Office during the great war. The IVe'lcome Bureau of Scientific Research makes contributions from its departments of protozoology, helminthology, bacteriology. and experimental pathology. The Museum of Medical Science demonstrates its original method of visual teaching. The Entomological Field Laboratories have exhibits dealing with mosquitos and mosquito-borne disease and its prevention. The exhibits of the. Wellcome Physiological Research Laboratories deal with the physiological, pharmacological, and serological problems met with in the production of diphtheria, tetanus, and other antitoxins. The Chemical Research Laboratories contribute groups of medicinal agents such as antimalarial, amoebicidal, anthelmintic, antileprotic etc. The Wellcome Historical Medical Museum telks the story of the progress of British medicine and surgery during the past 100 years by means of portraits and records of over fifty British pioneers, while dioramas and action pictures contribute visual records of outstanding developments in medicine and surgery due to British workers. The central cases contain historical collections of surgical instruments and pharmaceutical products. Maps and statistical charts show the growth of the public health services in London during the past 100 years.

\section{Experiments on Animals in Prussia}

The recent edict of General Göring, forbidding all experiments on living animals in Prussia, had scarcely reached the newspapers of this country before its inevitable modification was announced. The Berlin correspondent of the Times, telegraphing on September 8 th, states that pending the enactment of an Animal Protection Act vivisection is now defined as the dissection of, or operations on, a living unnarcotized animal in cases where anaesthetics are used for similar operations on the human body, and in cases where the use of anaesthetics is feasible. "As serious where the interest of maintaining health and life cannot dispense with scientific experiments with animals, these experiments will not be regarded as vivisection if the following rules are followed: Scientific experiments with animals may be made in scientifically conducted institutions under the supervision of their heads only if scientific considerations promise definite success. They must be omitted if the question at issiue has already been cleared up. They are to be made painless by general or local narcotics."

\section{Corrigendum}

St. Thomas's Hospital old students' dinner (see Journal, September 9th, p. 515)-the chairman's name should read Dr. Charles Richard Box.

\section{Vacancies}

Notifications of offices vacant in universities, medical colleges and of vacant resident and other appointments at hospitals, will be found at pages $36,37,38,39,42$, and 43 of our advertisement columns, and advertisements as to partnerships, assistantships, and locumtenencies at pages 40 and 41 . A short summary of vacant posts notified in the advertisement columns appears in the Supplement at page 168 